\title{
An Experimental Study: Cartoon Videos as Media Instruction on Students Speaking Ability
}

\author{
Siswandi1, Firman Rizaldi ${ }^{2}$, \\ Faculty of Education and Teacher Training, \\ State Islamic University of Sultan Syarif Kasim Riau, \\ Pekanbaru, Riau, Indonesia \\ firmanrizaldi22@gmail.com ${ }^{1}$, siswandi@uin-suska.ac.id ${ }^{2}$
}

\begin{abstract}
The main focus of this research is to investigate whether there was a significant difference in the speaking ability between the tenth grade students of SMA N 1 Kampar Timur. This research was classified as a quasi-experimental study. It involved 65 students of two groups, Class X MIPA 5 as the experimental group and Class $X$ MIPA 6 as the control group. The experimental group was taught by using cartoon videos, whereas the control group was taught by using the textbook-based technique. The data were obtained by using a pre-test and a post-test. The pre-test was given to both groups before the treatment and the post-test was given after the treatment. The data of the pre-test and post-test of both groups were analyzed by using descriptive and inferential statistics. The data were calculated by using a computer program, SPSS 25 for Windows. After the data were tested and found to be homogeneous and normal, the hypothesis was tested using the Kolmogrov-Smirnov test. The results of the research show that there was a significant difference in the speaking ability between the students who were taught by using cartoon video and those who were taught by using the textbook-based technique. The significance value calculated 0.019 is bigger than 0.05 (sig value $=0.109>0.05$ ). Therefore, the hypothesis of this study is rejected. It means that there is no significant difference on students speaking ability who are taught by cartoon video as instructional media at the eleventh grade of senior high school 1 Kampar Timur.
\end{abstract}

Keywords: Cartoon Videos, Speaking Ability, Media Instruction

\section{INTRODUCTION}

Speaking English becomes a tool for producing and acquiring knowledge in any language. It is also vital in communication because humans utilize it practically every time they communicate with another human being. As stated by Arbain et.al (2017) The most significant skill for English learners to acquire is speaking collectively of the four talents in English. For many people, the success of learning a language is measured by 
how far the student can talk and communicate in the target language. Therefore, the teacher has to make creative methods to teach Speaking subjects by using a media of teaching speaking. Learning through media of cartoon Videos can be one of the solutions to motivate students' interest in learning English. (Etemadi, 2012).

Media such a cartoon movie can be used by the teacher to aid in the teaching and learning process. however, the type of cartoon movie that will be shown in the classroom and is appropriate for teaching purposes According to Lonergan (1985), in Suparta (2016) The following groups of cartoon movies can be found: first, cartoon movie recordings of specialists' films and television programs. The second category includes domestic television broadcast cartoon movie recordings. Last but not least, there are animated film records of language training broadcasts and films.

Based on a preliminary researcher at SMA N 1 Kampar Timur by asking the English teacher, the researchers found the students still have problem in mastering speaking skills, especially in Pronunciation and vocabulary.

To solve the problem above, the researcher uses Cartoon videos media to improve students' speaking abilitity. Audiovisual media includes cartoon videos. Based on Fitrona et.al (2016) Students view a short cartoon movie at the beginning of the class and then retell the story in pairs, which is an alternate strategy for teaching speaking to senior high school students. It is a good strategy that can be applied by the teachers because it provides some advantages. The use of cartoon movies can help the students to more understand and memorize the story before they are going to retell the story in front of the class.

Based on the formulation of the problems above, this research is necessary to be carried out to achieve the objectives of the research as follows: first, to find out whether there is or not any significant effect of using cartoon videos as Media Instruction On Students Speaking Ability at SMA N 1 Kampar Timur. Then, to find out on which component of speaking ability does the use of cartoon videos media have the biggest effect on students' speaking ability.

\section{LITERATURE REVIEW}

Speaking is a valuable ability since it allows people to express themselves and share information with others. Speaking skill is particularly crucial in English learning, according to Fitrona et.al (2016), because it makes it easier for someone to convey information or ideas with others. As Stated by Waode (2018), Speaking, on the other hand, mostly refers to the use of that language in communication. The success of speaking ability is determined by the frequency with which the language is used. In other words, speaking English fluently will be tough without practice. English has become the most important language of communication in one of the world's languages.

In both teaching and learning, speaking is considered a skill to practice and master. In this light, the author states, "Speaking is the productive oral skill." It involves developing a system of meaningexpressing verbal utterances. Based on Kamonpan (2010) Speaking is one among the four macro skills necessary for effective communication in any language particularly when speakers 
don't seem to be using their first language. As English is universally used as a method of communication, especially within the internet world, English speaking skills should be developed together with the opposite skills in order that these integrated skills will enhance communication achievement both with native speakers of English and other members of the international community.

In addition, Speaking is not only one of the four skills which play a significant role for students in mastering English. It should be studied and practiced persistently. According to Brown (2004:141) there are five basic types of speaking or oral production where the students are expected to carry out in the classroom. They are imitative, intensive, responsive, interactive, and extensive.

Furthermore, According to Barker's (2009, in Afrilyasanti and Furthermore, According to Barker's (2009, in Afrilyasanti and Basthomi, 2011:557), state that the best way to keep our students interested and engaged in lessons is by making them interactive. These activity pages give information on how to enable students to analyze cartoons videos while using currently relevant materials as a guideline for lessons. The design of teaching using the cartoon to develop 21-century learners can be described into pre-teaching, whilst-teaching, and post-teaching:

Pre-teaching activity is the opening of the teaching and learning process. In this stage, the teacher greets the students and prays together with them and then checks students' attendance. After that, the teacher leads the students to do brainstorming by asking the students questions to recall the previous lesson; it can also help the teacher to make sure that the students are ready to study. The teacher also gives motivation by telling them the goals of the lesson and competencies that should be reached by the student at the end of the lesson. This pre-teaching activity spends time about 10 minutes.

There are three phases that researcher used, there are:

1) Show the students the cartoon videos and let them to watch it until the end.

2) And then, the writer explain about the simple present tense material with Power-Point Slide

3) After that, the writer done the question and answer with the students one by one.

The post-activity was employed to look into the student product such as the video that the students made.

\section{METHOD}

This research was experimental. According Creswell (2008), Quasi Experimental design is tested and idea (or practice or procedure) to find out whether its influence an outcomes ort dependent variables. Video was used to make the experimental group a special treatment. The control group was given the traditional method without video, which is textbook-based, as is normally done by the instructor. The research was conducted in February 2022 at Senior High School 1 Kampar Timur in Academic year 2020/2021

The number of the population is 197 students. Considering the population of this research is large, the researcher used Cluster random sampling to take the sample. The samples of this research are the students of X MIPA 5 as experimental class and 
$\mathrm{X}$ MIPA 6 as control class which both consisted of 65 students.

This research used a quasiexperimental design. In conducting the research, the writer conducted try out to test the validity and reliability of test items. The test that was used in collecting the data of the research was multiple-choice questions that consisted of twenty items and a short-answer question consisted of five items. The questions were made based on indicators that were stated in the syllabus used by Senior High School 1 Kampar Timur.

After testing validity and reliability, the writer conducted a pretest and posttest in both the experimental and control class. The treatment was given in the experimental class. After completing the research, the data was analyzed through the Independent Sample T-test formula by using SPSS 21.0 Version. The data was collected using the test. The test was used to find out the students' speaking ability. the students made a simple present tense video for the pre- test, and then the writer gave a cartoon video as a treatment of this research, after that the students made a simple present tense video again as the post- test.
There were two techniques of analyzing the data of this research, namely descriptive and inferential statistics. In the descriptive analysis, there were two formulas used in the computation; the mean and the standard deviation analysis. In the inferential statistics, this research used test of normality, test of homogeneity, and test of hypothesis. The data will be analyzed by using independent sample t-test, based on Pallent (2010) an independent sample t-test was used when we want to compare the mean score on some continuous variable for two different groups of subject, to find out whether there is or there is no significance difference between two or more variables can be analyzed by using sample $\mathrm{t}$ - test by using SPSS (statistical product and service solutions) 21.0 version program.

\section{FINDINGS AND DISCUSSION}

Before examining the effect of using cartoon video media on students' speaking ability at SMA N 1 Kampar Timur, the writers can be percentage into the scores as follows:

Table 4.1.

Percentage Experimental Class Pre-Test

\begin{tabular}{ccccc}
\hline No & Categories & Score & Frequency & Percentage \\
\hline 1 & Excellent & $80-100$ & 0 & $0.00 \%$ \\
2 & Good & $66-79$ & 7 & $20.59 \%$ \\
3 & Average & $56-65$ & 15 & $44.12 \%$ \\
4 & Poor & $40-55$ & 12 & $35.29 \%$ \\
5 & Fail & $30-39$ & 0 & $0.00 \%$ \\
& Total & & 34 & $100 \%$ \\
\hline
\end{tabular}


The table 4.1. shows that the category of excellent got the frequency $0(0 \%)$, the category of Good got the frequency $7(20.59 \%)$, the category of average got the frequency $15(44.12 \%)$.
The category of poor got the frequency $12(35.29 \%)$, and for the fail category got the frequency $0(0.00 \%)$ Then; the highest percentage was 15 (44.12\%).

Table 4.2.

Percentage Experimental Class Post-Test

\begin{tabular}{ccccc}
\hline No & Categories & Score & Frequency & Percentage \\
\hline 1 & Excellent & $80-100$ & 1 & $0.00 \%$ \\
2 & Good & $66-79$ & 15 & $44.12 \%$ \\
3 & Average & $56-65$ & 14 & $41.18 \%$ \\
4 & Poor & $40-55$ & 4 & $11.76 \%$ \\
5 & Fail & $30-39$ & 0 & $0.00 \%$ \\
& Total & & 34 & $100 \%$ \\
\hline
\end{tabular}

The table 4.2. shows that the category of excellent got the frequency $1(2.94 \%)$, the category of Good got the frequency $15(44.12 \%)$, the category of average got the frequency $14(41.18 \%)$.
The category of poor got the frequency $4(11.76 \%)$, and for the fail category got the frequency $0(0.00 \%)$ Then; the highest percentage was $15(44.12 \%)$.

Table 4.3.

Percentage Control Class Pre-Test

\begin{tabular}{ccccc}
\hline No & Categories & Score & Frequency & Percentage \\
\hline 1 & Excellent & $80-100$ & 1 & $3.23 \%$ \\
2 & Good & $66-79$ & 18 & $58.06 \%$ \\
3 & Average & $56-65$ & 9 & $29.03 \%$ \\
4 & Poor & $40-55$ & 3 & $9.68 \%$ \\
5 & Fail & $30-39$ & 0 & $0.00 \%$ \\
& Total & & 34 & $100 \%$ \\
\hline
\end{tabular}

The table 4.3. shows that the category of excellent got the frequency $1(3.23 \%)$, the category of Good got the frequency $18(58.06 \%)$, the category of average got the frequency 9 (29.03\%).
The category of poor got the frequency $3(9.68 \%)$, and for the fail category got the frequency $0(0.00 \%)$ Then; the highest percentage was $18(58.06 \%)$. 
Table 4.4.

Percentage Control Class Pre-Test

\begin{tabular}{ccccc}
\hline No & Categories & Score & Frequency & Percentage \\
\hline 1 & Excellent & $80-100$ & 1 & $3.23 \%$ \\
2 & Good & $66-79$ & 10 & $32.26 \%$ \\
3 & Average & $56-65$ & 12 & $38.71 \%$ \\
4 & Poor & $40-55$ & 8 & $25.81 \%$ \\
5 & Fail & $30-39$ & 0 & $0.00 \%$ \\
& Total & & 34 & $100 \%$ \\
\hline
\end{tabular}

The table 4.4. shows that the category of excellent got the frequency 1 $(3.23 \%)$, the category of Good got the frequency $10(32.26 \%)$, the category of average got the frequency $12(38.71 \%)$.
The category of poor got the frequency $8(25.81 \%)$, and for the fail category got the frequency $0(0.00 \%)$ Then; the highest percentage was $12(38.71 \%)$.

Table 4.5.

Independent Sample T-Test

\begin{tabular}{|c|c|c|c|c|c|c|c|c|c|c|}
\hline & \multicolumn{2}{|c|}{$\begin{array}{c}\text { Levene's } \\
\text { Test for } \\
\text { Equality of } \\
\text { Variances }\end{array}$} & \multicolumn{7}{|c|}{ t-test for Equality of Means } \\
\hline & & \multirow{2}{*}{$\mathrm{F}$} & \multirow[b]{2}{*}{ Sig. } & \multirow[b]{2}{*}{$\mathrm{t}$} & \multirow[b]{2}{*}{ df } & \multirow{2}{*}{$\begin{array}{l}\text { Sig. (2- } \\
\text { tailed) }\end{array}$} & \multirow{2}{*}{$\begin{array}{c}\text { Mean } \\
\text { Difference }\end{array}$} & \multirow{2}{*}{$\begin{array}{l}\text { Std. Error } \\
\text { Difference }\end{array}$} & \multicolumn{2}{|c|}{$\begin{array}{l}95 \% \text { Confidence } \\
\text { Interval of the } \\
\text { Difference }\end{array}$} \\
\hline & & & & & & & & & Lower & Upper \\
\hline $\begin{array}{l}\text { Speaking } \\
\text { Ability }\end{array}$ & $\begin{array}{l}\text { Equal variances } \\
\text { assumed }\end{array}$ & .297 & .588 & 1.620 & 63 & .110 & 3.281 & 2.026 & -.76715 & 7.329 \\
\hline & $\begin{array}{l}\text { Equal variances } \\
\text { not assumed }\end{array}$ & & & & 62.995 & .109 & 3.281 & 2.016 & -.74783 & 7.310 \\
\hline
\end{tabular}

Based on The table 5 above, independent sample t-test shows that sig (2-tailed) value was 0.110 . it can be stated that $0.110>0.05$ hypothesis $(\mathrm{Ha})$ is rejected. It can be interpreted that the alternative hypothesis (Ho) is accepted and null hypothesis (Ha) is rejected. It means that there is no significant difference on students' speaking ability who are taught by cartoon video as instructional media at the tenth grade of senior high school 1 Kampar Timur.

Finally, the score of students' speaking ability who did posttest by using cartoon videos as media instruction at senior high school 1 kampar timur was getting mean score 64.76. It concluded that the students' speaking ability was categorized "Low". 


\section{CONCLUSION}

The results of the research show that there was a significant difference in the speaking ability between the students who were taught by using cartoon video and those who were taught by using the textbook-based technique. The significance value calculated 0.110 is bigger than $0.05 \quad$ (sig value $=0.110>0.05$ ). Therefore, the hypothesis of this study is rejected. It means that there is no significant difference on students speaking ability who are taught by cartoon video as instructional media at the eleventh grade of senior high school 1 Kampar Timur.

\section{REFERENCES}

Arbain, \& Nur, D. R. (2017). Techniques for Teaching Speaking Skill in WidyaGama Mahakam University. Journal of Linguistic and English Teaching, 13-25.

Aziz, A., Nadia, S. R., Annas, S. R., Muniri, \& Surahmat. (2020). Improving Student Achievement Using Flipchart Based Cooperative Learning in Tulungagung . Universal Journal of Educational Research, 46284633.

Azlina, K., \& Eliwarti, N. (2012). A study on Speaking Ability of the SecondYear Student of SMK Telkom Pekanbaru. 1-13.

Brown, D. (2004). Language Assesment: Principles and Classroom Practices. United States of America: Pearson Education.

Creswell, J. W. (2012). Educational Reserach . Boston: Pearson.

Fitrona, H., \& Don, N. (2016). Teaching Speaking By Using
Short Cartoon Movies To Senior High School Students. Journal of English Language Teaching, 105111.

Hamdi, S. (201594-100). The Role of Interactive Whiteboard on Classroom Management International Journal of Academic Research in Progressive Education and Development.

Hamed, T. (2010). Sampling Method in Research Methodology; How to choose a sampling technique for research. International journal of academic research in management (IJARM). 18-27.

Harris, D. (1969). Testing Language as a Secind Langage. New York: McGraw- Hill.

Kadaruddin. (2017). Use of ComputerBased Learning Multimedia at English Departement of Universitas Sembilanbelas November Kolaka. International Journal of Education \& Literacy Studies, 49-56.

Kamonpan, B. (2010). Enhancing the development of speaking skills for non- native speakers of English. Elsevier, 1305-1309.

Khaldun, I. (2019). The Effect of Using Animations Film on Students Speaking Ability at SMK Darel Hikmah Pekanbaru.

Lai-Mei, L., \& Masoumeh, A. S. (2017). An Analysis of Factors Influencing Learners' English Speaking Skill. International Journal of Research in English Education, 34-31.

Moh, I., Fuzi, B., \& Muslimin. (2019). The An Analysis of Students' Speaking Ability on Specific Purpose of Learning. Linguistics and English Language Teaching Journal, 33-40. 
Pallant, J. (2016). SPSS Survival Manual.New York. Everbest Printing.

Rizky, A. (2016). An Analysis of Selected Eleventh Grade English Textbooks. Journal of English and Education, 109-126.

Rosdiana. (2017). The essential of realia: establishing writing ability to the real world. Getsempena English Education Journal (GEEJ) 172-178.

Samira, A. H. (2014). Speaking Difficulties Encountered by Young EFL Learners International Journal on Studies in English Language and Literature (IJSELL), 22-30.

Suparta, R. (2016). Using Cartoon Movie to Improve Speaking Skill. Research in English and Education (READ), 161-168.

Tanti, S. (2015). The Utilization Of Instructional Media In Teaching English To Young Learners. Journal of English and Education ,90-100.

Waode, H. (2018). Developing Students Speaking Ability Through Story Completion. Journal of English Language Teaching, 57-64. 